\title{
The Subaltern Speaks in Anna Weamys' A Continuation of Sir Philip Sidney's Arcadia: A Foucauldian Perspective
}

\author{
Dr. Merve Aydoğdu Çelik \\ Tekirdă̆ Namık Kemal University, School of Foreign Languages \\ merveaydogducelik@hotmail.com
}

\begin{abstract}
This paper examines how the servant Mopsa in Anna Weamys' A Continuation of Sir Philip Sidney's Arcadia provides a negative answer to Gayatri Chakravorty Spivak's question whether the subaltern can speak. In accordance with Michel Foucault's thoughts on power and resistance, it intends to reveal that the subaltern, contrary to what Spivak proposes, is able to raise voice and demonstrate resistance. Mopsa has not been given the chance to speak among the royals in Sir Philip Sidney's The Countess of Pembroke's Arcadia, but Weamys deconstructs Sidney's version and provides Mopsa the opportunity to transcend subalternity as she asserts her action and voice. Within this framework, Anna Weamys' romance can be read, in the context of Foucault's theory on power, as a challenge against Spivak's assumption which contends that the subaltern is not recognizable.
\end{abstract}

Keywords: Renaissance, romance, subaltern, power, resistance.

\section{Madun Konuşuyor: Anna Weamys'in A Continuation of Sir Philip Sidney's Arcadia'sına Foucault'cu Bir Bakış}

Öz

Bu makale Anna Weamys'in A Continuation of Sir Philip Sidney's Arcadia eserinde hizmetçi Mopsa'nın Gayatri Chakravorty Spivak'ın madunun konuşup konuşamayacağ hususundaki sorusuna nasıl olumsuz bir cevap oluşturduğunu inceler. Çalışma, Michel Foucault'nun iktidar ve direniş düşüncesi doğrultusunda, Spivak'ın önerdiğinin aksine, madunun sesini yükseltebileceğini ve direniş gösterebileceğini ortaya koyar. Sir Philip Sidney'in The Countess of Pembroke's Arcadia eserinde kraliyet üyeleri arasinda Mopsa'ya konuşma fırsatı verilmez, fakat Weamys, Sidney'in yorumunu altüst eder ve onun eylem ve sesini duyurmasına olanak vererek maduniyetini aşma fırsatı sağlar. Bu çerçevede, Anna Weamys'in romans1, Foucault'nun iktidar teorisi bağlamında, Spivak'ın madunun tanınmasının imkânsızlığı hususundaki varsayımına karşı bir meydan okuma olarak değerlendirilebilir.

Anahtar Kelimeler: Rönesans, romans, madun, güç, direniş. 


\section{INTRODUCTION}

Romance was an unfavorable genre for the sixteenth and seventeenth century reviewers. The customary attitude to the genre was disapproval as it was associated with unchecked behavior. In The Instruction of a Christian Woman (1523), Juan Luis Vives preaches that it is better "for [the girls] to enter into life blind and deaf, as our Lord says in the gospel, rather than to be cast into the fire of hell with both eyes and both ears" (74) by being engaged in romances; in The Anatomy of Melancholy (1621), Robert Burton believes that romance is read only by "silly Gentlewomen" who are "incensed by reading amorous toyes" and "set on fire" (qtd. in Hackett, 2000, p. 66); in Tom of All Trades (1631), Thomas Powell argues that "in stead of Song and Musicke, let them [daughters or wives] learne Cookery and Laundrie. And in stead of reading Sir Philip Sidneys Arcadia, let them read the grounds of good huswifery" (qtd. in Hackett, 2000, p. 106). The commentary on the genre by moralists and educationalists shows that romance and women's preoccupation with it either as readers or authors meant unchastity, disobedience, and sensuality. The fear that the genre would trigger desires and action contrary to what the patriarchal culture permits rendered it inconvenient for women since it was thought that the female sex, once under its influence, would deny their culturally sanctioned roles, threaten the patriarchal rules, and ultimately disrupt the social hierarchy. In a social environment in which women could even read as far as men allows, a woman engaged in writing was thought only as "a docile user of the pen who follows men's instructions" (Ferguson, 1996, p. 154). Women were permitted to write as long as they remain within the confines of religious or patriarchal teachings.

Anna Weamys produces her one and only work in the secular genre, and completes Sidney's The Countess of Pembroke's Arcadia (1593). Despite the negative attitude to romance at the time, Weamys' work was not severely criticized. Still, based on the three pieces that precede A Continuation, it is arguable that neither her production nor her authorship was taken seriously. The publisher, whose name is unknown, praises the work only because Sidney transmigrates via Weamys' pen:

$$
\begin{aligned}
& \text { Marvel not to find Heroick Sidney's renowned Fansie pursued to a close by a Feminine } \\
& \text { Pen: Rather admire his prophetical spirit now as much, as his Heroical before ... In brief, } \\
& \text { no other than the lively Ghost of Sidney, by a happie transmigration, speaks through the } \\
& \text { organs of this inspired Minerva. (Weamys, 1994, p. 110) }
\end{aligned}
$$

The second piece written by James Howell also celebrates Weamys' artistry. Just like the publisher's note, Howell benefits from the transmigration analogy. His so-called commendatory poem underestimates Weamys' agency as an author: "If a Male Soul, by Transmigration, can / Pass to a Female, and Her spirits Man, / Then sure some sparks of Sydney's soul have flown / To flames, for 'tis the course of Enthean fire / To warm by degrees, and brains to inspire" (Weamys, 1994, p. 115). Both interpretations suggest that Sidney's spirit infuses into Anna Weamys. The other commendatory poem, written by an anonymous person who is identified only by the initials H. P. M., also rests on the transfer metaphor. According to its author, Weamys writes "... An end to what great Sydney did beget, / But never perfected, these Embryons she / Doth Mid-wife forth in full maturitie" (Weamys, 1994, p. 112). Weamys' authorial skill is taken lightly again because she is thought to act only as a midwife, not a mother, to the incomplete embryo Sidney has begotten. Sidney's legacy overshadows Weamys' literary endeavour in all cases. It is likely that Weamys and her text did not draw much attention in her lifetime or after she dies. As 
historical sources recording Anna Weamys' biography, her social context, and her motives to write a continuation are "tantalisingly absent" (Mitchell, 2005, p. ix), how her text or her literary enterprise was received by literary authorities at the time is based on scant information.

The scholarly work about A Continuation and Mopsa is also scarce. Yet, those who study on Anna Weamys and her work praise Weamys' authorship and underscore her significance in the history of women's writing. Cullen, the editor of the first scholarly edition of Weamys' work (published in 1994), celebrates her act of writing. He contends that Weamys is "no mere docilely derivative woman writer appending herself to a man's work" (1994, p. xliii). He asserts that "Weamys' having the fragment of a male precursor as the main source for her 'continuation' does not inevitably suggest an especially feminine subservience" (1994, pp. xxxi-xxxii). Kinney, likewise, argues that the work shatters Sidney's supremacy over the Arcadian material and provides "a kind of authorial power" (2009, p. 208). Cullen and Kinney point that Weamys rejects the gendered hierarchy in the literary domain. Mitchell handles Weamys' text as an important material both "for understanding the reception of Sidney by women readers and for tracing the development of prose fiction" (2005, p. ix). DeZur, in the same vein, opines that Weamys inserts female storytellers into the text to "emphasize appropriate responses to narrative texts" (2014, p. 123). Focusing on Mopsa and her storytelling, DeZur states that Weamys "creates a clear distance and distinction between the character and narrator" (2014, p. 123). Mitchell and DeZur focus on the technical and narratological aspects of A Continuation. Mitchell also evaluates the work as part of protofeminist literature. She argues that Weamys' female heroines "illustrate a real concern with how women might navigate the straits of female behaviour in a judgmental and partisan society" (2005, p. ix). Similarly, Derecho states that Weamys' work is sensitive, and thus somewhat antagonistic, to the culture she inhabits. As she puts, A Continuation gives Weamys "an opportunity to highlight the inequalities of women's and men's situations in their culture by creating new versions of earlier stories and producing a contrast between the old and new tales" (Derecho, 2006, p. 68). In this sense, Derecho qualifies the work "an example of early modern feminism" (2006, p. 68). Simonova also regards A Continuation as "a feminist rebuke" $(2015$, p. 202) to its source text. Just as they speak highly of Weamys' literary venture, the critics celebrate Weamys for the narrative space she allots to Mopsa. According to Eckerle, Mopsa "has the potential to rewrite her role in literary history as a symbol ... of women's narrative success" (2013, p. 175). Campbell, likewise, claims that Mopsa "subverts the traditional power structure as seen in the Arcadia in which men tell stories to women ... and women's stories are often cut short" (2006, p. 182). This study also proposes that $A$ Continuation have a significant place in the history of women's literature owing to its female author writing in a genre unacceptable for women and the protofeminist concerns it manifests. Most critics evaluate the text in terms of Anna Weamys' transgressive attempt to write a literary work and of the themes that prioritize women's issues. This paper is unique within the scholarly work written about Weamys because it applies literary theory to an early modern text. It handles Mopsa's characterization based on the theoretical framework provided by Spivak and Foucault.

Weamys revises certain episodes of Sidney's romance in which he silences women. Sidney employs the masculine possessive adjective to address future continuators: "But the solemnities of these marriages, with the Arcadian pastorals, full of many comical adventures happening to those rural lovers ... may awake some other spirit to exercise his pen in that 
wherewith mine is already dulled (Sidney, 1907, p. 630). Even though Sidney invites men to write an end to his work, Weamys does not hesitate to take up the challenge as a woman. Making use of Sidney's text as "a flexible template for her own independent fiction" (Hackett, 2000, p. 109), Weamys, with a female viewpoint, finishes the narratives he leaves incomplete. In this respect, Weamys' A Continuation (1651), "the second piece of original prose romance" (Hager, 2005, p. 419) produced by a woman in England, proves "an important landmark" (Travitsky, 1996, p. 253) in women's literature in terms of both its subject matter and female author, as a spokesperson for the critic of cultural practices. Weamys' revisionist work enables her to "challenge the traditional definition of femininity while re-building and consolidating new definitions that include new possibilities" (Dell'Abate-Çelebi, 2016, p. 25). Mopsa, who is being mocked at, marginalized, oppressed, and disenfranchised to speak due to both her social status and sex in Sidney's work, is taken seriously, empowered, given voice, and centralized in Weamys' romance. Within this framework, the present study aims to scrutinize how the servant Mopsa in Weamys' $A$ Continuation (1651) disproves Spivak's thesis that the subaltern cannot speak. Although Mopsa initially embodies her assertion that "the subaltern as female is even more deeply in shadow" (Spivak, 1994, p. 83) regarding her disadvantaged status in the royal society and subordinate voice as a woman, her position gradually shifts from subalternity to agency in $A$ Continuation. Thus, the work can be taken as a challenge against Spivak's thought while resting upon Foucault's theory with its promise on power, resistance, and recognizability for the subaltern.

\section{On Subaltern, Power and Resistance: Spivak and Foucault}

The subaltern as a collective term refers to people who are oppressed, subjugated, silenced, and pushed to the margins. The subaltern belongs to the inferior ranks of the society. Those who are subject to ruling groups and denied access to power, action, and authority constitute the subaltern. Oppression, lack of agency and power, silence, marginalization, and isolation characterize the subaltern's condition. Antony Gramsci, who introduces the term in the Prison Notebooks, uses it to refer to "subordinate", "instrumental", and "non-hegemonic groups or classes" (Hoare \& Nowell-Smith, 1999, p. 20). Within the framework of Mussolini's fascist government, he argues that rural peasants as an unorganized group would remain susceptible to the ideas of the ruling class, state leaders, and their culture as they do not have political or social consciousness of their own. He, for this reason, concludes that "subaltern groups are always subject to the activity of ruling groups" (Gramsci, 1999, p. 207). He is pessimistic because, bereft of political and social consciousness collectively, he claims that the subaltern can never measure up to the ruling groups.

Spivak, influenced by Gramsci's understanding of the term, in her seminal essay "Can the Subaltern Speak?" defines subaltern within the framework of colonialism. She criticizes how the white western intellectuals export Eurocentric ideology to people from nonwestern/colonized world. She analyzes the term within a gendered framework by reflecting on the situation of Indian sati women and their representation in the Western discourse. Spivak argues that the prohibition of the Hindu rite, in which a widow immolates herself upon her husband's death, notwithstanding seeming an act of "white men saving brown women from brown men" (1994, p. 93), indeed deprives them of freedom of choice. She notes that "one never encounters the testimony of the women's voice-consciousness" 
(Spivak, 1994, p. 93) in their case. They remain within the confines of the ruling group because "the benevolent impulse to represent subaltern groups effectively appropriates the voice of the subaltern and thereby silences them" (Morton, 2003, p. 56). The widows represent the subaltern: their choice to die on their husbands' funeral pyre is prohibited. Their voice is silenced; they are not allowed to act as they wish. In this respect, Spivak argues that the subaltern cannot speak for themselves, but they can only be spoken to or be spoken about because they are not given the opportunity to represent themselves in social or political milieu. They are not authorised to have access to speech and power, so they can only be represented by those in power. The presence of the subaltern in public depends on outside intervention, and subalternity means "the state of voicelessness and powerlessness" (Farr, 2019, p. 76).

Spivak states that epistemic violence is constitutive of subalternity. As she reckons, it refers "to constitute the colonial subject as Other ... the asymmetrical obliteration of the trace of that Other in its precarious Subject-ivity" (Spivak, 1994, p. 76). She argues that those in power claim that they know the Other in the society, and they see themselves as authorized to act on behalf of, and to speak for and about the Other. They thereby produce knowledge, which indeed essentializes, objectifies, marginalizes, and silences, to exploit the Other. Such knowledge formation would never be impartial, unbiased, or without subjugation. In the presence of epistemic violence and cultural oppression, the subaltern would only be defined in relation to their difference to the upper social strata. Designated to be submissive, silent and inferior, the subaltern would never be entitled to speech or self-representation. Spivak accordingly criticizes Deleuze and Foucault's assertion that "the oppressed, if given the chance ... on the way to solidarity through alliance politics ... can speak and know their conditions" (1994, p. 78) [emphasis in the original]. She indicates that the matter is not simply that the subaltern is unable to express their voice, but it is the problem of recognition. Rather than whether the subaltern is mute or not given the chance to speak, it is about being recognized as a speaking subject. What is more important turns out not to be able to speak but to be heard by those who are not the subaltern. What determines the subaltern position is not the non-existence of speech but those in authority who reject to listen to the subaltern. Such a condition naturally hinders the possibility for upward social mobility in favor of the subaltern. Spivak therefore interprets subalternity as a "structured place from which the capacity to access power is radically obstructed" (Morris, 2010, p. 8). In other words, she handles subalternity not as an identity but a predicament one needs to overcome. Subalternity, in this sense, becomes relational because it is influenced by the interaction among people based on their sex, race, and class.

In her analysis of the subaltern, Spivak seems to adopt the concept of power as a monolithic entity in which there are two binary oppositions as the oppressor and the oppressed. As such, power is possessed by a certain group, and it is handled "as the capacity of powerful agents to realize their own will over the will of powerless people, and the ability to force them do things which they do not wish to do" (Mills, 2003, pp. 34-35). The subaltern, in this sense, represents the powerless people who are compelled to obey the power holders. On the other hand, Foucault argues that power does not belong solely to a specific group of people, but it can freely circulate. He characterizes the concept of power substantially different from its traditional understanding which holds it as an entity imposed upon the powerless by the powerful. Foucault argues that power does not descend from above; it does not belong to those who have titles or to a specific institution, but anyone can become its 
producer, arbiter, and distributor. He states that "power is no longer substantially identified with an individual ... it becomes a machinery that no one owns" (1980, p. 156). It is no longer a property one can possess: "power is not something that is acquired, seized, or shared ... power is exercised from innumerable points, in the interplay of non-egalitarian and mobile relations" (1978, p. 94). Power, then, is a performance rather than a possession. Foucault does not directly associate power with individuals, but he emphasizes the connection between individuals and power: although it is "a comprehensive power over everyone" and it is "collective at its centre", power "is always individual at the point where it arrives" (2006, p. 75). He argues that individuals are both the object and subject of power, and when they interact with each other, they create multiple forms of relations of power. Foucault, therefore, states that "power is everywhere ... because it comes from everywhere" (1978, p. 93). Power permeates the society, and each individual influences and is subject to power relations in the society. Indeed, for Foucault, "a society without power relations can only be an abstraction" (1982, p. 791). In this respect, he also puts that power functions as a productive and liberating force in power relations. Contrary to the monolithic understanding of power constituted by two opposing elements, according to him, "where there is power, there is resistance, and ... this resistance is never in a position of exteriority in relation to power" (1978, p. 95). He asserts that resistance is not an external entity that diffuses in power, but it is an integral part of power. The very existence of power breeds and validates the existence of resistance while resistance also reiterates power. Power and resistance, in this sense, are inextricably linked to each other. Foucault seems to adopt an understanding of power more positive than that of Spivak by regarding it as an emancipatory force and pointing to the possibility of resistance against oppression. What is more, arguing that power is a notion which is not possessed but which circulates, he emphasizes that power relations cannot be transcended or dissolved, but they can be altered by means of the acts of individuals by which they can surmount societal constraints.

McLaren, who discusses the relationship between Foucault and feminism, puts that "in its productive, positive aspect, power creates new possibilities, produces new things, ideas, and relations; this is akin to what feminists call 'empowerment'" (2002, p. 41). With its emphasis on resistance and agency, Foucault's notion of power proves a useful tool to reflect on Mopsa in A Continuation contrary to Spivak's conclusion that "there is no space from which the sexed subaltern subject can speak" (1994, p. 103). Women should employ art and literature to express themselves and to challenge patriarchal discourse. This is indeed what Weamys aims at with $A$ Continuation because she not only gives voice to Mopsa that Sidney denies her earlier, but she also provides the circumstances in which Mopsa's presence is recognized and voice is heard by the royals. Weamys benefits from Sidney's text with a view of constituting a new possibility for empowerment for the subaltern by reproducing a new story with new ideas and relationships.

\section{Mopsa in Sidney's The Countess of Pembroke's Arcadia}

In Sidney's romance, Mopsa is the daughter of Dametas "the most arrant doltish clown ... beyond the degree of ridiculous" (Sidney, 1907, p. 14) and Miso "so handsome a bedlam, that only her face and her splay-foot have made her accused for a witch" (Sidney, 1907, p. 14). Mopsa, "issued forth" (Sidney, 1907, p. 14) by them, is no more beautiful than her parents. She is so ugly that her appearance is ridiculed with an anti-blazon as soon as she is involved in the narrative. Contrary to the princesses Philoclea and Pamela - King Basilius 
and Queen Gynecia's daughters - who are "over-excellent children ... in all the gifts allotted to reasonable creatures" (Sidney, 1907, p. 13), Mopsa "in whom no with can devise anything" has "virtues strange, and beauties such, as no man them may know" (Sidney, 1907, p. 14) and "foul complexion" (Sidney, 1907, p. 129). At this point, one should note that, according to early modern physiognomy, there is a reciprocal relationship between physical appearance and personality. As Baumbach explains,

\section{According to physiognomy ... the body is perceived as a legible 'text,' which openly communicates a person's character and provides an insight into the disposition of man, provided that all signifiers that become visible on the bodily surface are given careful consideration. (2010, p. 582)}

The Renaissance understanding of beauty was characterized by overlapping of one's physiology and inner beauty. The physical features were thought to signify one's character: the uglier a person was, the worse he/she was thought to be as a person while a lovely complexion stood for amicable personality, naivety, and goodness. A physically appealing person would immediately be thought to have an exemplary personality. The fact that one's disposition could be judged by how he/she looks like leads to Mopsa's marginalization as soon as she appears in Sidney's text. She is first and foremost a servant. She is ugly and halfwitted, and she does not have outstanding virtues or character. What is more, the antiblazon, recited by a male character and written by Sidney as the author, indeed "celebrates masculine creativity" in which Mopsa "is effectively silenced through being re-located within the bounds of literary descriptions of the beautiful" (Baker, 2007, p. 87). It, though vice versa, recalls the Petrarchan topos of the lady and the beloved in which the former is silenced so that the latter could express his woe and desire. Just as the Petrarchan tradition suppresses the female voice, makes women the object of male desire, and serves as a conduit for asserting male artistic competence, the anti-blazon reshapes and reproduces cultural ideals of beauty, and thereby serves merely to silence and immobilize its addressee. The anti-blazon both marginalizes and silences Mopsa as a hideous lower class woman.

Mopsa's subordinate position is also evinced by how she is treated by the princesses Pamela and Philoclea. When Philoclea stops recounting "the wonderful valour of the two princes", she desires "a breathing time" reckoning that the others would listen to her more eagerly later on and that she has "held the stage long enough" (Sidney, 1907, p. 195). She therefore invites his sister Pamela to complete the story she has left incomplete. Miso immediately intervenes to decide who will speak up next. She suggests to "draw cuts" so that "the shortest cut speak[s] first" (Sidney, 1907, p. 196). The company agrees unanimously. Mopsa gaining the "pre-eminence" (Sidney, 1907, p. 198) starts to speak. Halfway through her story, though, Philoclea breaks in and asks her to finish it on her marriage day in return for "the best gown" she has ever worn. Mopsa, hoping to reach a larger audience and happy to tell her tale in the wedding, accepts the bargain. Pamela starts to speak immediately after her. Mopsa, however, does not (or cannot because storytelling is not at stake in the wedding) tell the rest of her story all throughout the romance. Lamb puts that women "are not allowed to talk for very long" (1990, p. 94) in Sidney's romance and "despite its sympathy for women", the work "conveys a strong sense of the danger of women's speech" (Lamb, 1990, p. 90). Mopsa as a servant holds a less advantaged position because she is silenced by another woman who is more privileged than her. It is true that she seems to be recognized, taken seriously, and listened to initially, but the incident 
demonstrates her subalternity because she is never allowed to speak up again and recognized as a speaking subject in the wedding.

Moreover, Mopsa is only instrumental for Musidorus, who disguises as Dorus, to express his love for Pamela in Sidney's work. Mopsa's function in his plot is "to serve for a foil of her perfections" (Sidney, 1907, p. 14) and, even though Dorus woos Mopsa, he deceives her as he actually courts Pamela. Mopsa, however, is so dull that she cannot understand what is happening around her (Sidney, 1907, pp. 130-131). In an instance in which Dorus wants to be alone with Pamela, he makes up a fool's errand for Mopsa. He asks her to climb a tree and wait there silently until a voice calls her by name three times upon which she will be granted a wish by Apollo (Sidney, 1907, pp. 469-470). It is evident that Mopsa is included in the narrative as a minor character whose presence is trivial as an individual but whose function is important as a foil to Pamela. Not taken seriously, silenced, and travestied by others, Mopsa realizes her subalternity throughout the narrative.

\section{Mopsa in Weamys' A Continuation of Sir Philip Sidney's Arcadia}

Mopsa does not obediently accept subalternity in Weamys' work. Struggling against being silenced due to her class and sex, she collapses Spivak's postulate that the subaltern cannot speak. She appears as a self-sufficient woman seeking every chance to struggle for agency and identity. As Eckerle states, "recognizing in Mopsa a less privileged character who had experienced narrative injustice, Weamys sets out to right it and to recognize ... Mopsa's fondest desires" (2013, p. 185) in A Continuation. First of all, the text introduces her as the "sole heir" (Weamys, 1994, p. 166) to her father. The episode hints that the father is alive, but he never speaks or even appears in the text. The father's textual absence, which ensures Mopsa's independence from parental influence (the mother is not included in the narrative, either) and the daughterly obedience it would lead to, secures agency, and freedom of speech and action. Foucault argues that "power is exercised only over free subjects, and only insofar as they are free ... where the determining factors saturate the whole, there is no relationship of power" (1982, p. 790). In the same vein, the absence of an authority figure, embodied by fathers, brothers, or male elders of the family in the early modern age, provides Mopsa freedom to act however she wishes. Much as she is inferior compared to the royals due to being a maid, she is completely free as a woman (or as a daughter). In Foucauldian terms, Mopsa is a free subject bestowed "with a field of possibilities in which several ways of behaving, several reactions and diverse comportments may be realized" (Foucault, 1982, p. 790). There is not any determining factors or an authority figure that influences or restricts her behavior, and she is involved in power relations as an independent individual.

The absence of any physical description or an allusion to her character traits also serve to erase the unfavorable influence of Sidney's partial presentation in Arcadia. While he portrays Mopsa as an ugly and dim-witted person prior to and during her acts, Weamys does not provide foreknowledge as to her personality nor does she describe her physically. From a Foucauldian perspective, the absence of physical description empowers Mopsa because she is not subject to discourse on the Renaissance's ideal of beauty. Foucault emphasizes the interrelation between discourse and power. Discourse refers to "ways of constituting knowledge, together with the social practices, forms of subjectivity and power relations which inhere in such knowledges and relations between them" (Weedon, 1987, p. 108). It can produce knowledge; it can change the meaning of social practices; it can 
influence power relations; and, it can restrain or liberate individuals. That is, discourse produces power and power produces knowledge. Accordingly, in the Renaissance, the notion of ideal beauty is created through discourse of aesthetics, which defines external comeliness as indicative of inner beauty. In this sense, the fact that there is not the slightest clue of how Mopsa looks like liberates her from the derogatory effect of discourse on beauty. It shatters the nexus between discourse and power. Weamys invalidates the discourse that Sidney employs to ridicule her because there lacks the physical detail upon which Mopsa could be evaluated. In other words, Weamys does not control the way she would be judged simply by physical description. She gives Mopsa the space by which she can establish identity and exert resistance.

One might argue that lack of physical description is a form of erasing woman's body. On the other hand, in line with the critique of patriarchal practices, men have been held responsible for estranging women from their own bodies, and it has been argued that the male gaze has objectified the female body and caused women to regard their own bodies as sexual objects (Fredrickson \& Roberts, 1997, p. 175). Nonetheless, from the feminist perspective, the female body has also gained importance as the manifestation of women's power in late modernity. Once the body is seen as the central object over which relations of power are played out, it has been thought that the female body is not merely a locus of patriarchal oppression, but it can also function as a site of resistance. The female body, thus pivotal in relations of power, serves as a source of knowledge, subjectivity, and struggle simultaneously. As a socially inscripted entity, it is thought to "promote symbolic rebellion ... and self-transformation" (Pitts, 2003, p. 49) in favour of women, and it is seen "as integral to the development of self identity, and ... self-actualization" (Pitts, 2003, p. 50). In other words, women's reclaiming their body from its objectification serves as an expression of agency and subjectivity against the relations of power that subjugate them. As the female body, when it is instrumental for the feminist cause, blurs the dichotomous relationship between the mind and body, the feminists assert that women can benefit from their corporeality as central to their political struggle. The French feminists Kristeva, Irigaray, and Cixous also adopt a notion of the body that rejects traditional binary oppositions. This, however, was not the case in the early modern era. Corporeality was the polar opposite of the mind. The female body, being feeble and fragile, was seen worse than the male body. The categories of mind and body functioned in favour of the patriarchal culture accordingly. There was a hierarachical relationship between the mind and body in which the former had a higher value than the latter. While men were associated with the mind and culture, women were associated with the body and nature. Thus, mind/body dichotomy further devalued women, qualified them less than men intellectually, and assigned them a secondary status. In this sense, lack of physical details does not necessarily erase Mopsa's agent position in $A$ Continuation. It, instead, disturbs the binary opposition between the mind and body and its respective associations. The narrative does not focus on what Mopsa looks like, which shortcircuits her association directly with the body, but it focuses on what she sets to state, which thereby, emphasizes her mind over her corporeal presence. Considering that the body was not seen central to agency, but it had negative connotations, lack of physical description does not hinder Mopsa's subjectivity. Rather, the reader's reaction is shaped not by her appearance but by her speech.

Mopsa, who is resolute to complete her tale, takes the initiative to become a speaking subject who produces the counter-discourse to evolve into the producer of an alternative 
form of knowledge. She does not accept to be an object of mockery, humiliation, and subordination. Instead, becoming a resisting subject, she gains voice, authority, and identity when she defies the existing power relations. As soon as she is included in the plotline, Mopsa appears to be an upright and ambitious person. She straightforwardly expresses her will to continue her story to get the gown:

\begin{abstract}
Fair Princess, I intend not to forget the promise you made me, when I told you a part of a curious tale, how you assured me your Wedding Gown, if I would afford to finish my Storie on that welcom day: but now the greatest part of the day is run away, and you are raised so high on your tip-toes, that you do not vouchsafe me to be in your books, but choose rather to gaze upon these strange sights, than to remember me, or your Gown. (Weamys, 1994, p. 166)
\end{abstract}

Mopsa reproaches that the princess has not yet kept her promise. She speaks in a serious, self-confident, demanding, and resolute manner. The incident highlights Mopsa's altered position: she is no longer devoid of voice depicted in Sidney's text but becomes a speaking subject to obtain what she thinks she is entitled to. In Foucault's view, "[p]ower exists only when it is put into action" (1982, p. 788). Mopsa likewise gains the upper hand in the relationship as soon as she expresses her demand. It should be noted, though, in the remainder of the quotation, Foucault states that power requires recognition, and a power relationship can only be realized when both parties recognize each other: "that 'the other' (the one over whom power is exercised) be thoroughly recognized and maintained to the very end as a person who acts" (1982, p. 789). That is, although Mopsa's action is significant per se, Philoclea's response as the authorized power holder over Mopsa as a princess becomes more significant. Philoclea does not ignore or get angry with her. She does not break her promise, either. She recognizes Mopsa: Philoclea cannot help but "forbear blushing to hear [Mopsa] reprove so sharply" and "to make her silent for the present, she renew[s] her promise" (Weamys, 1994, p. 166). The reaction indicates that Philoclea accepts Mopsa as a speaking subject who is capable of action. It is interesting that while the servant is thought to be timid, silent, and patient, it is the princess who blushes and feels guilty. Their reaction blurs the rigid distinction between the classes they represent. The former assumedly complies with what the latter instructs, but Mopsa is the one to command in their case. Their dialogue reflects the mutability of power relations in that as soon as Mopsa rejects to perform her assigned role, Philoclea surrenders.

Mopsa also realizes that anyone can show resistance in a power relationship. As Foucault asserts, power relations "depend on a multiplicity of points of resistance: these play the role of adversary, target, support, or handle in power relations. These points of resistance are present everywhere in the power network" (Foucault, 1978, p. 95). Mopsa's insistence likewise alters Philoclea's action because each individual is subject to resistance, and nobody is excluded from its influence. Indeed, seeing that "Mopsa very impatiently stay[s] out the vanishing of their Scenes", Philoclea, devoid of choice, "smilingly [leads] Mopsa by her hand into the middest of the Royal companie, where she [leaves] her to exercise her discretion" (Weamys, 1994, p. 166). Agency of an individual becomes the determining factor in this a process of resistance and containment. As Giddens records, "to be able to 'act otherwise' means being able to intervene in the world ... Action depends upon the capacity of the individual to 'make a difference' to a pre-existing state of affairs" (1984, p. 14). Making a difference refers to agency, and agency is realized through exercise of power. Everyone in the power network is endowed with the potential to resist, transform, reinforce, reverse, 
appropriate, or attain power, and everyone could conduct the course of events. In the power relationship between Philoclea and Mopsa, power is transformed from the former to the latter: Mopsa resists Philoclea's disregard, and she eventually attains power. In other words, it is owing to Mopsa's agency to "act otherwise" that she can govern the affairs to "make a difference" in the royal network.

Mopsa soon consolidates power when she gets Pyrocles' attention: “[Philoclea] discovered to her Paramour Pyrocles, Mopsa's ambition, who immediately caused all noises to be hushed, that he might with the greater attention hearken to Mopsa, and observe all her actions" (Weamys, 1994, p. 166). It is notable that he silences everyone in the hall and decides to listen to Mopsa attentively. Mopsa's attracting the attention of everyone is important as it signifies power. One should also remember that there is a closely-knitted relationship between power and subalternity. In this sense, Pyrocles' decision to listen to Mopsa serves as a catalyst for her emancipation. Mopsa exceeds subalternity because, for the first time, she is not instructed what to do. She is not spoken to/about, but she autonomously speaks out. She is recognized as an individual. As Farr relates, "any movement outside of voicelessness ... means a movement out of subalternity toward power" (2019, p. 73). Mopsa gradually transcends subalternity because the more she does not keep silent, the more she earns power. The episode demystifies the constructed nature of social roles and fluidity of power relations by showing how a simple act can disturb the social hierarchy once individuals do not settle in the place allotted to them. Weamys thereby negotiates the possibility for transgressing the territory the subaltern occupies, and Foucauldian power as a liberating force stands out.

It is known that Mopsa wants to tell a story because she aims to get the gown. Considering the discourse on clothing within the seventeenth-century framework, the gown also becomes as important as Mopsa's afore-analyzed act. Clothing meant more than simply covering the body in the early modern era. It worked as "a semiological distinction" (Guillory, 1996, p. 76) to indicate social and sexual differences. It was thought that there is a natural correspondence between one's dress and social status (and sex), and thus everyone was expected to conform to the dress code as it demarcated class identity and regulated the social distinctions in the society. Stubbes, for instance, in Anatomie of Abuses (1583) complained that there was class confusion due to disregarding the dress code:

\section{[N]ow there is such a confuse mingle mangle of apparell in England, and such horrible excesse thereof, as euery one is permitted to flaunt it out, in what apparel he listeth himself, or can get by any meanes. So that it is very hard to knowe, who is noble, who is worshipfull, who is a Gentleman, who is not. (qtd. in Wald, 2014, p. 69)}

Dress signified the divisions of rank, and violating the dress code was frowned upon as it was seen as a threat to social hierarchy and associated with class transgression or discontent with one's place in the society. The maidservants, who must have been thought to emulate their mistresses, were specifically the target of instruction: "In 1611 the Common Council in London ruled against those waiting-women and chambermaids who flouted the sumptuary laws by parading in large ruffs ... fancy aprons and ribbons" (Burnett, 1997, p. 127). There was social control imposed by religious and legal authorities to maintain class division, and apparel "became a primary site where a struggle over the mutability of the social order was conducted" (Howard, 1988, p. 422) in the early modern age. Foucault argues that discourses produce meaning, subjects, and societal realities, and there is strong 
connection between discourse and power because power relations could modify the meanings, subjects, and realities. As he records, "discourse can be both an instrument and an effect of power ... a point of resistance and a starting point for an opposing strategy. Discourse transmits and produces power", but it also "renders it fragile and makes it possible to thwart" (1978, p. 101). In the same vein, despite the discourse that naturalizes social division, the anxiety regarding the dress code reveals the malleability of class/gender distinctions and vulnerability of power relations. Mopsa benefits from the seventeenthcentury discourse on clothing as an instrument to her own purpose. She employs it as a tool to modify the existing power structure. Her wish to get the gown becomes disruptive as it connotes her aspiration to move up to a higher status. Much as it is certain that she cannot transcend her class only by possessing a royal dress, the fact that she appropriates it indicates agency that poses a challenge to the neatly-organized class distinction. The gown becomes metonymic for power which shatters her subalternity. The fact that Philoclea eventually gives Mopsa the gown concretizes her power, which renders it a sign/point of resistance.

The story Mopsa recounts, which focuses on a romantic relationship between a maiden and a knight, is also an important act in terms of Foucauldian framework because it serves as a tool to foster power in the royal network. As Foucault argues, power "is produced from one moment to the next, ay every point, or in every relation from one point to another" (1978, p. 93). Mopsa's story, likewise, enables her to produce power in the relationship with the royals because she both makes herself heard within a coterie of people who are more powerful than her based on rank, and she is able to complete the story she is not allowed to in Sidney's text. The mini romance includes a strong-willed woman and a kidnapped man as well as nymphs, witches, and magical incidents. The maiden who engages in a romantic relationship with a knight, who elopes with him fearlessly, and who goes on a quest to save him eventually, the water nymphs who abduct the knight, the aunts who hand the maiden magical nuts, and the old witch who tells her how to use them and who ultimately helps release the knight from bondage collectively turn the seventeenthcentury patriarchal culture upside down. While men are thought to be stronger, wiser, and more courageous than women, and women are thought to be weak, fainthearted, and less intelligent, the story inverts gender roles in which there is no damsel-in-distress but an abducted knight desperately waiting for rescue. In Mopsa's tale, the savior or the protector of virtues is not a male. The knight is not the hero to conclude the tale saving the maiden. Instead, the maiden acts, thinks, and initiates an action to save him. Their relationship shatters automatized gender roles for men and women.

Mopsa's mini romance is significant in many aspects. It foregrounds female agency as an-initially-unobtrusive maiden is given space to achieve formidable deeds relentlessly. The maiden is not the victim of an arranged marriage, which would commodify her, but she chooses whom to marry on her own accord without paternal interference. The story gives more importance to individual experience than social rules as the maiden is neither interrogated nor punished due to an extramarital love affair. Instead of virtues traditionally ascribed to women, it rewards female desire in conclusion. It emphasizes solidarity among women as the maiden is helped by others. It deconstructs the hierarchical relationship between the supposedly superior and inferior as assigned gender roles are reversed and women gain the upper hand. It refashions the witch figure (witches were supposed to carry the features in contrast to ideal womanhood) as she proves being beneficial by helping the 
release of the knight from captivity and thereby shattering the credibility of patriarchal discourse. Mopsa serves as the mouthpiece for Anna Weamys by whose storytelling she resists the patriarchal discourse and gender bias. Indeed, giving Mopsa the opportunity to complete her protofeminist story that Sidney does not allow her earlier, Weamys provides an enslavement-release model for those who are stuck within the confines of the dominant. In this sense, the story establishes Mopsa's presence and empowers her both as a speaker among the royals and the female characters who challenge patriarchal discourse.

At this point, it should be noted that the English society was patriarchal when Weamys wrote her work. The patriarchal household was compromised of the man as the master of house, the woman, their children, servants, and the cattle. Being just above the livestock, the servants used to hold the lowest place in rank. Within the paterfamilias, a female servant's state must have been worse than that of a male servant as she was in a more disadvantaged position due to her sex. As well as obeying the rule of the master, his wife and children, the female servant also had to fulfill the essentials of ideal womanhood such as chastity, piety, meekness, and obedience. In other words, she was thought to be emblematic of the healthy maintenance of patriarchal social system. Mopsa, however, shows resistance against such a seemingly unbreakable power relation. Contesting subalternity, she tries to establish her existence against the backdrop of a patriarchal framework. Her determination to tell a tale of protofeminist content among the royals empowers her. Challenging social class structure and internalized gender roles, Mopsa's storytelling functions to cement the discourse in accordance with the demands of the subaltern. Foucault states that "every power relationship implies ... a strategy of struggle" (1982, p. 794). Mopsa's resolution to recount the story is also a strategy of resistance against the authority of the royals and expresses her forwardness to establish autonomy because power exists so long as there is a possibility for resistance. Mopsa thereby establishes her identity as a speaking female subject against those who underestimate her. As Eckerle points out, "she not only achieves narrative closure ... but achieves her own happy ending as well, for she finds her voice long enough to insist on her rights, to put Philoclea in her place, and to get her dress" (2013, p. 183). Mopsa appears in the text just once, and she fulfils what she aims at before she leaves the scene. Hers is truly a success story.

A critical reader, though, might reckon that Mopsa's subaltern position is perpetuated by Weamys herself because she includes Mopsa in the plotline only once. It is a misjudgement since Mopsa is not a minor or instrumental character, as she is in Sidney's text, but an individual with specific motives. Moreover, given that Weamys completes only the stories Sidney leaves unfinished, rather than introducing new characters or a new subplots, it is inevitable that the work would be episodic. Weamys does not divide the romance into sections, but she goes on with a different set of characters as soon as she reaches a narrative closure (except for the very last scene which culminates in the marriages of the characters previously introduced: Pamela marries Musidorus, and Philoclea marries Pyrocles). In this sense, Mopsa's one-time appearance in the plotline does not indicate that her subalternity is reinforced. What is more, lack of details as to what happens to her afterwards is not peculiar to Mopsa. Weamys does not go into particulars several times. For example, she does not recount Queen Helena's joy as it would be "too great for [her] dull expression" (Weamys, 1994, p. 134) or she does not relate the fight among the knights because "it goes beyond [her] memorie to declare all the passages thereof" (Weamys, 1994, p. 158). She does not mention the happiness of the Arcadian court, either. She thinks that "it 
would make two large a storie to recount all their discourses" (Weamys, 1994, p. 162). In other words, be it a queen or a servant, Weamys treats her characters alike. She abstains from giving details to reach a resolution as quickly as possible. Her closure-oriented strategy obstructs proliferation of the narrative. It seems that narrative closure matters Weamys more than the writing process. It turns out to be the reason why she "concludes many of Sidney's complex storylines in a remarkably direct manner (her entire text is a mere 89 pages compared to Sidney's hundreds)" (Eckerle, 2013, p. 182). Considering Weamys' writing strategy and her authorial motive, it is evident that she has no intention to maintain Mopsa's subalternity.

\section{CONCLUSION}

Mopsa as a servant woman, both in Sidney's and Weamys' romances, represents the subaltern due to her gender and class in the social context. She is doubly underprivileged because of her disadvantaged social status. However, that Mopsa is silenced in Sidney's work does not lead to a tragic servant figure in Weamys' romance since Weamys interrogates and rehabilitates the cultural assignments that marginalize Mopsa due to sex and rank.

In Weamys' A Continuation, the peripheral servant figure modifies power relations because the royals no longer regard her simply a servant but recognize her as an individual with a voice of her own. Mopsa's protest against her being silenced and her insistence on completing her story to possess the gown render her powerful and thereby recover her from subalternity. The paper relies on these two instances, and Mopsa transcends her place in both of them. The text does not contain any other moments in which she is depicted as a dominant figure who disrupts power dynamics or as a victimized one who is completely disregarded by the royals. The text also lacks any clue whether Mopsa's status remains the same as a servant or it is rehabilitated once she completes her story because Weamys finishes the narration as soon as Philoclea gives Mopsa the gown. Therefore, it is inconclusive that Mopsa has been triumphant only temporarily, or she will remain a servant as she has always been. On the other hand, owing to her struggle for power, it is certain that Mopsa does not end up as a subalterm figure.

By defying Spivak's theory on subalternity, Mopsa emerges as a resisting Foucauldian subject who ultimately gains recognition in the royal society thanks to her ambitious character. Spivak contends that to assume the subaltern to be competent enough to resist is unrealistic, and it should be circumvented because the resistance of the subaltern would never be recognized. She argues that neither the resistance nor the agency of the subaltern would be substantial within the framework of authorized discourse, and cultural, economic and political mechanisms of production. Foucault, on the other hand, who argues that power is producible in any moment, in any point, and in any relationship, is much more optimistic than Spivak, and he believes that given that power can influence and be exerted to those who are free, they can independently map solutions to be able to resist power. Now that the very presence of power generates potential for struggle, resistance, and agency, the subaltern should find out ways to get a voice, to be heard, and to be recognized as Mopsa centuries earlier does. 
Article Information

Ethics Committee Approval: Informed Consent:

Financial Support:

Conflict of Interest:

Copyrights:
Exempt from the Ethics Committee Decision.

No participant

No financial support from any institution or project.

No conflict of interest.

No material subject to copyright is included. 


\section{BIBLIOGRAPHY}

Baker, N. (2007). 'To make love to a deformity': praising ugliness in early modern England. Renaissance Studies, 22(1), 86-109. Retrieved from https://www.jstor.org/stable/24417349.

Baumbach, S. (2010). Physiognomy. In M. Hattaway (Ed.), A new companion to English Renaissance literature and culture (pp. 582-97). Oxford: Wiley-Blackwell.

Burnett, M. T. (1997). Masters and servants in English Renaissance drama and culture: Authority and obedience. London: Macmillan.

Campbell, J. (2006). Literary circles and gender in early modern Europe: A cross-cultural approach. Aldershot: Ashgate.

Cullen, P. C. (1994). Introduction. In P. C. Cullen (Ed.), A Continuation of Sir Philip Sidney's Arcadia (pp. xvii-lxxiii). Oxford: Oxford University Press.

Dell' Abate-Çelebi, B. (2016). Penelope's daughters. Nebraska: Zea Books.

Derecho, A. (2006). Archontic literature: a definition, a history, and several theories of fan fiction. In K. Hellekson \& K. Busse (Eds.), Fan fiction and fan communities in the age of the internet: New Essays (pp. 61-78). Jefferson: Macfarland \& Company.

DeZur, K. (2014). Gender, interpretation, and political rule in Sidney's Arcadia. Newark: University of Delaware Press.

Eckerle, J. A. (2013). Romancing the self in early modern Englishwomen's life writing. Farnham: Ashgate.

Farr, P. M. (2019). Subalternity as margin and center of anachronistic discourse. Çankaya University Journal of Humanities and Social Sciences, 13(1), 62-78. Retrieved from https://dergipark.org.tr/tr/download/article-file/750866.

Ferguson, M. W. (1996). Renaissance concepts of the 'women writer.' In H. Wilcox (Ed.), Women and literature in Britain, 1500-1700 (pp. 143-68). Cambridge: Cambridge University Press.

Foucault, M (1978). The history of sexuality volume 1: An introduction (R. Hurley, Trans). New York: Random House.

Foucault, M. (1980). Power/knowledge: Selected interviews and other writings 1972-1977 (C. Gordon, L. Marshall, J. Mepham, K. Soper, Trans.) New York: Pantheon.

Foucault, M. (1982). The subject and power. Critical Inquiry, 8(4), 777-95. Retrieved from https://www.jstor.org/stable/1343197.

Foucault, M. (2006). Psychiatric power: Lectures at the Collège de France 1973-74 (G. Burchell, Trans.) Basingstoke and New York: Palgrave Macmillan.

Fredrickson, B. L. \& T. A. Roberts. (1997). Objectification theory: toward understanding women's lived experiences and mental health risks. Psychology of Women Quarterly, 21, 173-206.

Giddens, A. (1984). The constitution of society: Outline of the theory of structuration. Oxford: Polity Press.

Gramsci, A. (1999). Selections from the Prison Notebooks. London: The Electric Book Company. 
Guillory, J. (1996). From the superfluous to the supernumerary: reading gender into Paradise Lost. In E. Harvey \& K. E. Maus (Eds.), Soliciting interpretation: Literary theory and seventeenth-century English poetry (pp. 68-88). Chicago: The University of Chicago Press.

Hackett, H. (2000). Women and romance fiction in the English Renaissance. Cambridge: Cambridge University Press.

Hager, A. (Ed.). (2005). Encyclopedia of British writers: 16th and 17th centuries. New York: Facts on File.

Hoare, Q. \& G. Nowell-Smith. (1999). Preface. In Q. Hoare \& G. Nowell-Smith (Eds.), Selections from the Prison Notebooks (pp. 13-21). London: The Electric Book Company.

Howard, J. E. (1988). Cross-dressing, the theatre and gender struggle in early modern England. Shakespeare Quarterly, 39(4), 418-40. doi: 10.2307/2870706.

Kinney, C. (2009). Undoing romance: Beaumont and Fletcher's resistant reading of The Countess of Pembroke's Arcadia. In M. E. Lamb \& V. Wayne (Eds.), Staging early modern romance: Prose fiction, dramatic romance, and Shakespeare (pp. 203-218). New York: Routledge.

Lamb, M. E. (1990). Gender and authorship in the Sidney circle. Madison: University of Wisconsin Press.

McLaren, M. A. (2002). Feminism, Foucault, and embodied subjectivity. New York: State University of New York Press.

Mills, S. (2003). Michel Foucault. London and New York: Routledge.

Mitchell, M. (2005). Anna Weamys. London and New York: Routledge.

Morris, R. (2010). Introduction. In R. Morris (Ed.), Can the subaltern speak?: Reflections on the history of an idea (1-18). New York: Columbia University Press.

Morton, S. (2003). Gayatri Chakravorty Spivak. London: Routledge.

Pitts, V. L. (2003). In the flesh: The cultural politics of body modification. Basingstoke and New York: Palgrave Macmillan.

Sidney, P. (1907). The Countess of Pembroke's Arcadia. London: Routledge. (Original work published 1593)

Simonova, N. (2015). Early modern authorship and gender in early modern Europe: Adaptation and ownership from Sidney to Richardson. Basingstoke: Palgrave Macmillan.

Spivak, G. C. (1994). Can the Subaltern Speak? In P. Williams \& L. Chrismas (Eds.), Colonial discourse and post-colonial theory: A reader (pp. 66-111). New York: Columbia University Press.

Travitsky, B. S. (1996). The possibilities of prose. In H. Wilcox (Ed.), Women and literature in Britain, 1500-1700 (pp. 234-66). Cambridge: Cambridge University Press.

Vives, J. L. (2000). The instruction of a Christian woman: A sixteenth century manual. Chicago: The University of Chicago Press.

Wald, C. (2014). The reformation of romance: The Eucharist, disguise, and foreign fashion in early modern prose fiction. Berlin and Boston: De Gruyter. 
Weamys, A. (1994). A Continuation of Sir Philip Sidney's Arcadia. Oxford: Oxford University Press. (Original work published 1651)

Weedon, C. (1987). Feminist practice and poststructuralist theory. London: Blackwell. 